УДК 676.017.3; 620.2

В.В. ТКАЧУК, О.Ю. РЕЧУН

Луцький національний технічний університет

О.А. ПРЯДКО

Наџіональний університет біоресурсів і природокористування України

\title{
ДОСЛІДЖЕННЯ СУЧАСНИХ ПРОБЛЕМ УКРАЇНСЬКОГО РИНКУ ЦЕЛЮЛОЗНО-ПАПЕРОВОЇ ПРОДУКЦЇ̈
}

\author{
В.В. ТКАЧУК, О.Ю. РЕЧУН \\ Луикий национальный технический університет \\ О.А. ПРЯДКО \\ Национальний университет биоресурсов и природопользования Украиньл \\ ИССЛЕДОВАНИЯ СОВРЕМЕННЫХ ПРОБЛЕМ УКРАИНСКОГО \\ РЫНКА ЦЕЛЛЮЛОЗНО-БУМАЖНОЙ ПРОДУКЦИИ
}

\author{
V. TKACHUK, O. RECHUN \\ Lutsk national technical university
}

O. PRIADKO

National university of life and environmental sciences of Ukraine

\section{RESEARCH OF CURRENT PROBLEMS OF THE UKRAINIAN MARKET OF CELLULOSE-PAPER PRODUCTS}

\section{https://doi.org/10.36910/6775-2310-5283-2019-12-25}

Мета. Визначення проблем розвитку ринку целюлозно-паперової продукиії, окреслення шляхів їх вирішення.

Результати. Встановлено, щуо ринок целюлозно-паперової продукиї активно розвивається. Целюлозно-паперова промисловість є важливою галуззю економіки України. Украӥна є експортером такої продукиї на європейський ринок, а, отюе, вітчизняна продукиія є конкурентоспроможною та якісною. Проте існує імпортозалежність від закордонної сировини, яка є дороговартісною. Маючи хороші промислові потужності $з$ виробництва паперової продукиії, слід шукати альтернативні джерела власної рослинної сировини, аби даний ринок розвивався потужніше. В Украйні функиіонує понад 20 підприємств, щуо виробляють паперову продукцію в Украӥні, проте матеріально-технічна база їх застаріла.

Найважливішими видами продукції целюлозно-паперової промисловості є цеелюлоза, папір, картон. За обсягами виробнищтва паперу провідні місия у світі традиційно займають розвинуті країни: США, Японія, Канада, Німеччина. Найбільшими експортерами ї̈ є Канада, та деякі європейські краӥни - Швеція, Фінляндія, Норвегія, Австрія, а імпортерами - США, великі європейські краӥни, Японія.

Вагомим фактором зміни імпортозалежності від закордонної сировини є пошук альтернативних джерел власної вітчизняної сировини для виготовлення иелюлознопаперової продукиї, проведення наукових досліджень щэодо технологій переробки такої продукиї та активне впровадження у виробництво.

Наукова новизна. Встановлено динаміку експорту-імпорту иелюлозно-паперової 
продукції Україною.

Практична значимість. Зважаючи на проведений аналіз украйнського ринку целюлозно-паперової продукиї, можна зробити висновок про перспективність його розвитку, адже промислові потужності в намій краӥні є, існує сформована нормативнотехнічна база, проте є проблема із недостатністю вітчизняної сировини, адже основним матеріалом для їі виробництва $\epsilon$ макулатура. Вагомим фактором зміни імпортозалежності від закордонної сировини є пошук альтернативних джерел власної вітчизняної сировини для виготовлення ичелюлозно-паперової продукції, проведення наукових досліджень щуодо технологій переробки такої продукиії та активне впровадження у виробництво.

Ключові слова: целюлозно-паперова промисловість, целюлоза, папір, картон, ринок, iмnорт, експорт.

\section{Постановка проблеми у загальному вигляді та ії зв'язок із} важливими науковими чи практичними завданнями. Целюлозно-паперова продукція - товар, який користується щоденним попитом, споживання якого в Україні зростає. Целюлозно-паперова промисловість є важливою галуззю економіки України. Функціонує понад 20 підприємств, що виробляють паперову продукцію в Україні, проте матеріально-технічна база їх застаріла. На ринку даної продукції відчутною проблемою є недостатність сировинних ресурсів (макулатури, деревної маси, целюлози тощо). Тому через імпорт сировини, яка $\epsilon$ досить дорогою, підприємства даної промисловості встановлюють досить високі ціни на свою готову продукцію.

В Україні існує Загальнодержавна цільова програма розвитку целюлознопаперової промисловості України та вітчизняного ринку картонно-паперової продукції на період до 2020 року, яка покликана вирішити вище окреслені проблеми галузі.

Світові обсяги виробництва целюлозно-паперової продукції неухильно зростають, як зростає i попит на неї. Підприємства 3 iї виготовлення зосереджені передусім у США, Канаді, Японії, Швеції, Фінляндії, Росії. Значна частина цієї продукції випускається у Німеччині, Франції, Чехії, Польщі, Норвегії, Австрії. Найбільшими експортерами іiі є Канада та деякі європейські країни - Швеція, Фінляндія, Норвегія, Австрія, а імпортерами США, великі європейські країни, Японія.

Найважливішими видами продукції целюлозно-паперової промисловості є целюлоза, папір, картон. За обсягами виробництва паперу провідні місця у світі традиційно займають розвинуті країни: США, Японія, Канада, Німеччина. Швидко збільшуються обсяги виробництва паперу в деяких країнах, що розвиваються, таких як: Китай, Індія, Мексика. У Китаї значну частину паперу виробляють 3 рисової соломи [1]. 
Аналіз останніх досліджень, у яких започатковано вирішення проблеми. Проблемам ринку целюлозно-паперової продукції приділяють увагу багато вчених. Зокрема, Л. Андрієвська досліджує особливості розвитку ринку паперових виробів санітарно-гігієнічного призначення, окреслює проблеми його розвитку, цінові сегменти даного ринку, асортимент тощо [2]. Т. Глушкова свої праці присвятила сучасним тенденціям розвитку ринку картонно-паперових виробів [3]. Використання соломи льону олійного для створення сировинної бази льону олійного вивчала С. Путінцева [1], дослідження ринків олійних культур досліджено у праці [4]. Методами покращення захисних властивостей займаються такі науковці як Н. Мережко, В. Свідерський [5].

Цілі статті. Метою даної публікації $\epsilon$ аналіз проблем на ринку целюлозно-паперової продукції, визначення шляхів їх вирішення, аналіз асортименту та обсягів імпорту даних товарів.

Об'скт дослідження - целюлозно-паперова продукція, що імпортуєтьсяекспортується в (з) Україну (и).

Виклад основного матеріалу дослідження 3 повним обгрунтуванням отриманих наукових результатів. Проаналізувавши ринок целюлознопаперової продукції, варто зазначити, що останніх 15 років найбільш популярними видами паперу є папір для друку, таропакувальні целюлознокомпозиційні матеріали, газетний папір та санітарно-гігієнічний. Для цієї галузі важливим є пошук альтернативної сировини, яка б здешевлювала високу вартість паперу 3 целюлози. Найбільшими виробниками паперу $є$ США, Канада, Японія, Росія, Китай, Німеччина, Фінляндія, Швеція, Італія (табл. 1). Головні постачальники целюлозних напівфабрикатів, паперу й картону на світовий ринок - Канада, Швеція, Фінляндія, Норвегія [1].

Таблиця 1

Основні світові експортери та імпортери паперової продукції

\begin{tabular}{|l|c|c|c|}
\hline Основні експортери & $\begin{array}{c}\text { Обсяг експорту, } \\
\text { тис.т }\end{array}$ & Основні імпортери & Обсяг імпорту, тис.т \\
\hline Фінляндія & 11520 & Німеччина & 9494 \\
\hline Німеччина & 8830 & Велика Британія & 7554 \\
\hline Франція & 4805 & Франція & 6051 \\
\hline Італія & 2587 & Італія & 4397 \\
\hline
\end{tabular}

Розглянемо структуру експорту-імпорту України целюлозовмісної продукції за 2017 рік. Згідно з інформацією, що подана базою даних UN Comtrade [6], Україна досі ввозить найбільше такої продукції з Росії, Польщі, 
Угорщини та Німеччини (табл. 2), причому, порівняно з 2016 роком, об'єми імпорту зросли. Отже, ми продовжуємо залишатися імпортозалежними від дорогої закордонної продукції, а, отже, ціни на паперову продукції в Україні будуть зростати i далі. Тому слід шукати альтернативну українську целюлозовмісну сировину, використовувати безвідходне виробництво, аби змінити таку ситуацію у майбутньому.

Таблиця 2

Перелік основних ринків постачання целюлози з деревини або інших волокнистих матеріалів, паперу або картону, що імпортувалися Україною у 2017 році

\begin{tabular}{|c|c|c|c|c|c|c|c|}
\hline 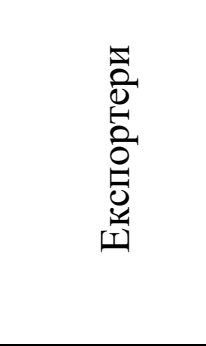 & 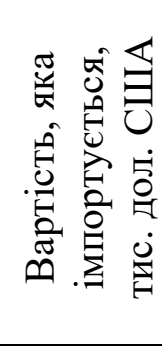 & 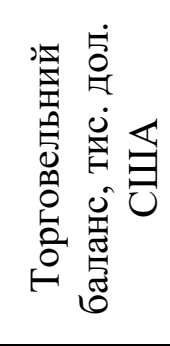 & 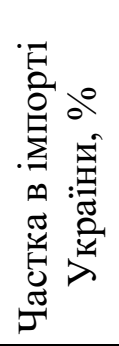 & 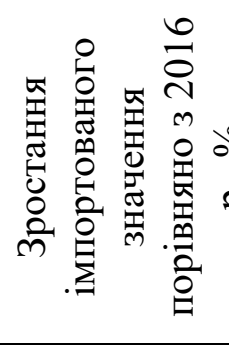 & 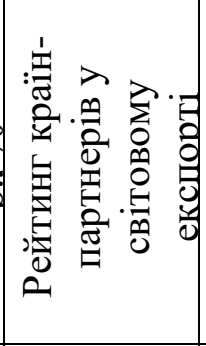 & 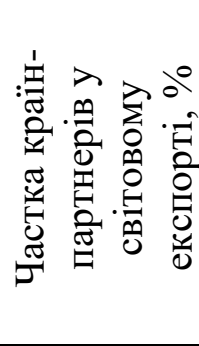 & 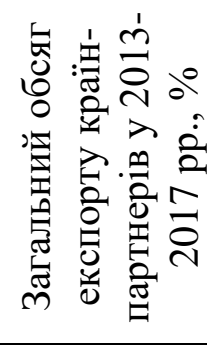 \\
\hline Світ & 112,220 & $-109,229$ & 100 & 33 & - & 100 & - \\
\hline $\begin{array}{l}\text { Російська } \\
\text { Федерація }\end{array}$ & 64,460 & $-64,460$ & 57,4 & 53 & 10 & 2,6 & 1 \\
\hline Польща & 14,813 & $-14,813$ & 13,2 & 28 & 23 & 0,6 & 13 \\
\hline Угорщина & 4,441 & $-3,586$ & 4 & 31 & 40 & 0,2 & 6 \\
\hline Німеччина & 3,889 & $-3,693$ & 3,5 & 64 & 8 & 3,2 & -2 \\
\hline США & 3,682 & $-3,682$ & 3,3 & 2 & 1 & 18,7 & -1 \\
\hline Румунія & 3,108 & $-3,047$ & 2,8 & 19 & 46 & 0,07 & 10 \\
\hline Молдова & 2,741 & $-2,708$ & 2,4 & 26 & 83 & 0 & 17 \\
\hline Швеція & 2,727 & $-2,727$ & 2,4 & -23 & 6 & 4,8 & -6 \\
\hline Фінляндія & 2,171 & $-2,171$ & 1,9 & 94 & 7 & 4,8 & 0 \\
\hline Білорусія & 1,583 & $-1,583$ & 1,4 & -61 & 66 & 0,02 & 6 \\
\hline Чехія & 1,068 & $-1,068$ & 1 & 45 & 21 & 0,8 & -1 \\
\hline Китай & 344 & -344 & 0,3 & -48 & 30 & 0,3 & 4 \\
\hline Австрія & 35 & 948 & 0 & -95 & 22 & 0,8 & -1 \\
\hline
\end{tabular}

3 таблиці 3 видно, що в трійці лідерів по експорту 3 Україною целюлозовмісної продукції є Австрія, Угорщина, Нідерланди, порівняно 3 2016 роком об’єми експорту зростають. Отже, Україна виробляє якісну конкурентоспроможну целюлозовмісну продукцію, яка користується попитом на європейському ринку. Адже целюлозно-паперова промисловість України об’єднує близько 100 підприємств із виробництва паперу, картону й виробів 3 них, а разом із переробниками, трейдерами, посередниками, науковими, 
монтажними та спеціалізованими торговельними організаціями їх налічується понад 300. У галузі працює майже 30 тис. осіб.

Таблиця 3

Перелік основних ринків імпорту целюлози з деревини або інших волокнистих матеріалів, паперу або картону, що експортувалися Україною у 2017 році

\begin{tabular}{|l|c|c|c|c|c|c|}
\hline Імпортери & $\begin{array}{c}\text { Вартість } \\
\text { експорту, } \\
\text { тис. дол. } \\
\text { США }\end{array}$ & $\begin{array}{c}\text { Торгове- } \\
\text { льний } \\
\text { баланс, } \\
\text { тис. дол. } \\
\text { США }\end{array}$ & $\begin{array}{c}\text { Частка } \\
\text { експорту } \\
\text { України, } \\
\%\end{array}$ & $\begin{array}{c}\text { Зростання } \\
\text { експрто- } \\
\text { ваного } \\
\text { значення } \\
\text { порівняно } \\
\text { 2016 p., } \\
\%\end{array}$ & $\begin{array}{c}\text { Загальний } \\
\text { партнерів у } \\
\text { світовому } \\
\text { імпорті }\end{array}$ & $\begin{array}{c}\text { приріст } \\
\text { імпорту } \\
\text { країн- } \\
\text { партнерів у } \\
2013-2017 \\
\text { рр., \% }\end{array}$ \\
\hline Світ & 2,991 & $-109,229$ & 100 & 146 & - & 1 \\
\hline Австрія & 983 & 948 & 32.9 & 375 & 17 & -2 \\
\hline Угорщина & 855 & $-3,586$ & 28.6 & 278 & 31 & 2 \\
\hline Нідерланди & 527 & 527 & 17.6 & 61 & 9 & -4 \\
\hline Тайланд & 263 & 263 & 8.8 & 0 & 14 & 8 \\
\hline Німеччина & 196 & $-3,693$ & 6.6 & 3 & 2 & -2 \\
\hline Румунія & 61 & $-3,047$ & 2 & -5 & 45 & 9 \\
\hline Італія & 48 & 37 & 1.6 & -56 & 4 & -3 \\
\hline Індія & 33 & $-2,708$ & 1.1 & 1,000 & 121 & 16 \\
\hline
\end{tabular}

Висновки та перспективи подальших досліджень. Зважаючи на проведений аналіз українського ринку целюлозно-паперової продукції, можна зробити висновок про перспективність його розвитку, адже промислові потужності в нашій країні $\epsilon$, існує сформована нормативно-технічна база, проте $є$ проблема із недостатністю вітчизняної сировини, адже основним матеріалом для іiі виробництва $є$ макулатура. В середньому імпортується близько $20 \%$ макулатури. Слід змінювати державну політику у сфері заготівельної діяльності підприємств целюлозно-паперової продукції. Вагомим фактором зміни імпортозалежності від закордонної сировини $\epsilon$ пошук альтернативних джерел власної вітчизняної сировини для виготовлення целюлозно-паперової продукції, проведення наукових досліджень щодо технологій переробки такої продукції та активне впровадження у виробництво.

\section{Список використаних джерел}

1. Путінцева С.В. Сучасний стан і проблеми світового та українського ринків целюлозно-паперової продукції / С.В. Путінцева // Вісник ХНТУ. Технологія легкої $\mathrm{i}$ 
харчової промисловості. - 2016. - № 1. - С. 126-130.

2. Андрієвська Л. Основні тенденції розвитку вітчизняного та світового ринку паперових виробів санітарно-гігієнічного призначення / Л. Андрієвська // Товари і ринки. 2010. - №1. - С. 41-46.

3. Глушкова Т. Стан, проблеми та сучасні тенденції розвитку ринку картоннопаперових виробів в Україні / Т. Глушкова // Вісник Київ. нац. торг.-екон. ун-ту. — 2005. № 2. - С. 71-75.

4. Ткачук В.В. Формування ринку технічних культур в Україні / В.В. Ткачук, С.В. Ягелюк, О.Ю.Речун // Технічні науки та технології: науковий журнал. - Чернігів: ЧНТУ, 2018. - № 1. - C. 196-206.

5. Мережко Н.В. Кремнійорганічні покриття для захисту матеріалів з різним ступенем реформованості / Н.В. Мережко, В.А. Свідерський, Д.І. Аршинніков, К.В. Осауленко // International Scientific and Practical Conference "World Science" - C. 10-15.

6. База даних UN Comtrade [Електронний ресурс]. - Режим доступу: https://comtrade.un.org/

Цель. Определение проблем развития рынка цุеллюлозно-бумажной продукции, определение путей их решения.

Результаты. Установлено, что рынок иеллюлозно-бумажной продукиии активно развивается. Целлюлозно-бумажная промышленность является важной отраслью экономики Украины. Украина является экспортером такой продукиии на европейский рынок, а, следовательно, отечественная продукиия является конкурентоспособной $и$ качественной. Однако существует импортозависимость от зарубежного сырья, которая является дорогостоящей. Имея хорошие промышленные мощности по производству бумажной продукции, следует искать альтернативные источники собственной растительного сырья, чтобы данный рынок развивался мощнее. В Украине функционирует более 20 предприятий, производящих бумажную продукцию в Украине, однако материально-техническая база их устарела.

Важнейшими видами продукиии иеллюлозно-бумажной промышленности является целлюлоза, бумага, картон. По объемам производства бумаги ведущие места в мире традиционно занимают развитые странь: США, Япония, Канада, Германия. Крупнейшими экспортерами ее является Канада, и некоторые европейские страны Швеция, Финляндия, Норвегия, Австрия, а импортерами - США, крупные европейские страны, Япония.

Весомым фактором изменения импортозависимости от зарубежного сырья является поиск альтернативных источников собственной отечественного сырья для изготовления иеллюлозно-бумажной продукции, проведение научных исследований по технологиям переработки такой продукции и активное внедрение в производство.

Научная новизна. Установлено динамику экспорта-импорта иеллюлозно-бумажной продукции Украиньл.

Практическая значимость. Учитывая проведенный анализ украинского рынка целлюлозно-бумажной продукичи, можно сделать вывод о перспективности его развития, ведь промышленные мощңности в нашей стране есть, существует сформирована нормативно-техническая база, однако есть проблема с недостаточностью отечественного сырья, ведь основным материалом для ее производства является макулатура . Весомым фактором изменения импортозависимости от зарубежного сырья является поиск альтернативных источников собственной отечественного сырья для изготовления целлюлозно-бумажной продукции, проведение научных исследований по технологиям переработки такой продукции и активное внедрение в производство. 
Ключевые слова: целлюлозно-бумажная промышленность, цеелюлоза, бумага, картон, рынок, импорт, экспорт.

Purpose. Determination of problems of development of the market of pulp and paper products, outline ways of their solution.

Findings. It is established that the market of pulp and paper production is actively developing. The pulp and paper industry is an important branch of the Ukrainian economy. Ukraine is an exporter of such products to the European market, and, consequently, domestic products are competitive and high quality. However, there is an import dependence on foreign raw materials, which is expensive. With good industrial output for paper products, alternative sources of its own plant material should be sought in order to make this market more powerful. There are more than 20 enterprises that produce paper products in Ukraine, but the material and technical base of them is outdated.

The most important types of pulp and paper industry products are cellulose, paper, cardboard. By volume of paper production, the leading places in the world traditionally occupy the developed countries: the USA, Japan, Canada, Germany. Its largest exporters are Canada, and some European countries - Sweden, Finland, Norway, Austria, and importers - the USA, large European countries, Japan.

An important factor in changing import dependence on foreign raw materials is the search for alternative sources of own domestic raw materials for the manufacture of pulp and paper products, conducting research on technologies for the processing of such products and active introduction into production.

Originality. The dynamics of export-import of pulp and paper products by Ukraine is established.

The practical value. Taking into account the analysis of the Ukrainian market of pulp and paper products, we can conclude that it is promising for its development, because there are industrial capacities in our country, there is the established normative and technical basis, but there is a problem with the lack of domestic raw materials, as the main material for its production is paper waste. An important factor in changing import dependence on foreign raw materials is the search for alternative sources of own domestic raw materials for the manufacture of pulp and paper products, conducting research on technologies for the processing of such products and active introduction into production.

Key words: pulp and paper industry, pulp, paper, cardboard, market, import, export.

Стаття рекомендована до друку доктором технічних наук, професором Байдаковою Л.І. Дата надходження в редакиію 09.01.2019 p. 